\title{
Apparent Consumption vs. Total Consumption- A Lead-Acid Battery Case Study
}

Scientific Investigations Report 2006-5155 



\section{Apparent Consumption vs. Total Consumption- A Lead-Acid Battery Case Study}

By David R. Wilburn and David A. Buckingham

Scientific Investigations Report 2006-5155 


\title{
U.S. Department of the Interior DIRK KEMPTHORNE, Secretary
}

\author{
U.S. Geological Survey \\ Mark D. Myers, Director
}

\section{U.S. Geological Survey, Reston, Virginia: 2006}

For product and ordering information:

World Wide Web: http://www.usgs.gov/pubprod

Telephone: 1-888-ASK-USGS

For more information on the USGS — the Federal source for science about the Earth, its natural and living resources, natural hazards, and the environment:

World Wide Web: http://www.usgs.gov

Telephone: 1-888-ASK-USGS

Any use of trade, product, or firm names is for descriptive purposes only and does not imply endorsement by the U.S. Government.

Although this report is in the public domain, permission must be secured from the individual copyright owners to reproduce any copyrighted materials contained within this report.

Suggested citation:

Wilburn, D.R., and Buckingham, D.A., 2006, Apparent consumption vs. total consumption-A lead-acid battery case study: U.S. Geological Survey Scientific Investigations Report 2006-5155, 9 p. 


\section{Contents}

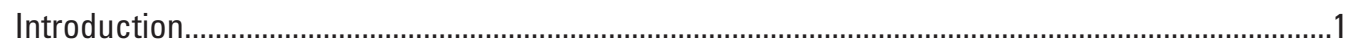

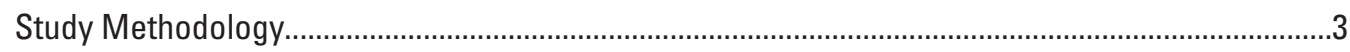

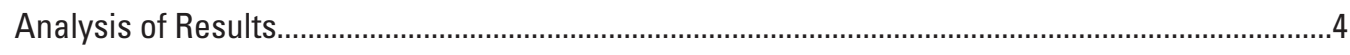

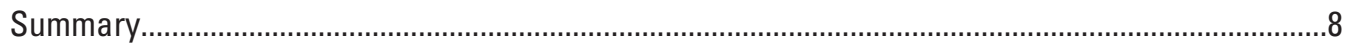

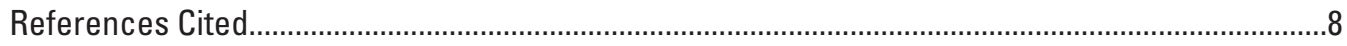

\section{Figures}

1. Chart showing U.S. total consumption of lead metal for 2004 ..........................................2

2. Photograph showing a lead-acid automotive battery ......................................................2

3-4. Graphs showing-

3. Comparison of lead apparent consumption data with total consumption data for the lead-acid battery sector for the years 1989 through 2004 ...............................4

4. Comparison of new lead-acid battery imports to the United States with imports from Mexic 0 ..................................................................................................... 5

\section{Tables}

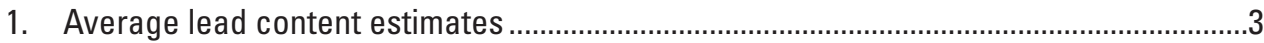

2. Lead contained in U.S. imported and exported lead-acid batteries and battery parts for selected years between 1989 and 2004 ...............................................6 



\title{
Apparent Consumption vs. Total Consumption- A Lead-Acid Battery Case Study
}

\author{
By David R. Wilburn and David A. Buckingham
}

\section{Introduction}

This report compares estimates of U.S. apparent consumption of lead with estimates of total U.S. consumption of this mineral commodity from a materials flow perspective. The difference, attributed to the amount of lead contained in imported and exported products, was found to be significant for this sector. The study also assesses the effects of including mineral commodities incorporated in manufactured products on the interpretation of observed trends in minerals consumption and trade.

Materials flow is a systems approach to understanding what happens to the materials we use from the time a material is extracted, through its processing and manufacturing, to its ultimate disposition. The U.S. Geological Survey (USGS) provides accurate and detailed mineral production and mineral commodity consumption statistics that are essential for government, nongovernment organizations, and the public to gain a better understanding of how and where materials are used and their effect on the environment and society.

Published statistics on mineral apparent consumption are limited to estimates of consumption of raw material forms (ore, concentrate, and [or] refined metal). For this study, apparent consumption is defined as mine production + secondary refined production + imports (concentrates and refined metal) - exports (concentrates and refined metal) + adjustments for government and industry stock changes. These estimates do not account for the amount of mineral commodities contained in manufactured products that are imported to the United States, nor do they deduct the amount of these mineral commodities contained in manufactured products that are exported from the United States.

When imports or exports of manufactured products contribute significantly to the total use of a particular raw material, an estimate of consumption that does not consider the incorporated forms of these mineral commodities within imported or exported manufactured products can be either under- or overreported (depending on the net trade flow). Factors that influence consumption and trade patterns include variations in industry structure, labor or financial markets, legislation, and technology. As U.S. trade patterns of manufactured products change, omitting mineral commodities incorporated into these goods as part of U.S. mineral commodity consumption estimates may affect the interpretation of observed trends in minerals consumption and trade.
Although it may be desirable to include minerals contained in manufactured products as part of consumption estimates, collection and estimation of these data are sometimes difficult. Consumption and trade data for every traded product may not be readily available. Compiling comprehensive consumption statistics for mineral commodities, which have many end uses, each including multiple products, may be time consuming. For these reasons, studies of all mineral commodities are not feasible. Mineral commodity selection for this study is based on data accessibility considerations and the relative importance of lead contained in imported and exported products when considered part of total U.S. lead consumption.

Lead was selected for this initial evaluation of total mineral consumption because of the need to understand the consumption pattern of this potentially toxic metal and its compounds, the relative simplicity of this sector's end-use structure, and the availability of trade data. This study draws upon the findings of an earlier lead consumption study (Biviano and others, 1999) conducted by the USGS for the period 1984 to 1993 , but uses a different study methodology for an industry whose structure has changed from that considered in the earlier study.

Figure 1 shows the quantity of material contributing to U.S. total consumption of lead metal from domestic and foreign industrial sectors in 2004, based upon trade data reported by the USGS and the U.S. International Trade Commission (USITC). For this study, total consumption is defined as primary and secondary refined lead production + refined metal imports for consumption + refined lead contained in imported products - refined lead exports - refined lead contained in exported products + adjustments for government and industry stock changes. The U.S. total consumption of lead metal is the sum of U.S. production from primary refineries and secondary recyclers, refined metal imports and exports, and shipments of lead scrap into and out of the United States. Included are estimates for the amount of lead contained in manufactured products that are imported and exported (of which about 85 percent are lead-acid battery products). Changes in U.S. Government stockpiles and industry stock changes are also included. For 2004, the U.S. apparent consumption of lead metal is reported as 1.44 million metric tons (Mt) (Gabby, 2006); however, when the quantity of lead contained in imported and exported manufactured products (colored boxes) is taken into account, the total U.S. consumption of lead metal is estimated to be about $1.78 \mathrm{Mt}$. Most of the difference between the two estimates, approximately 340,000 metric tons (t), can be 


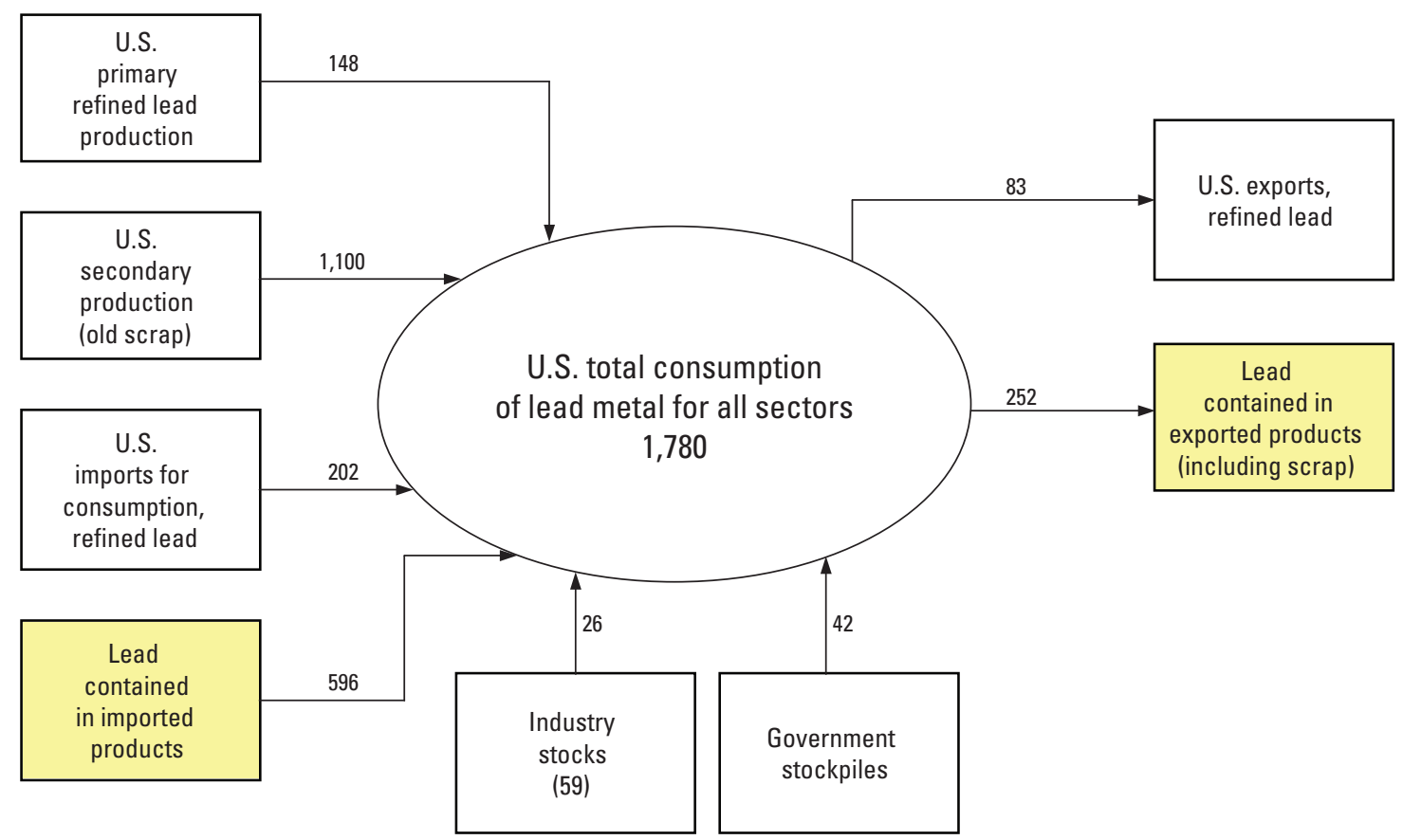

Figure 1. U.S. total consumption of lead metal for 2004. Total consumption defined as primary refined lead production + secondary lead metal production + refined lead metal imports for consumption + lead contained in imported products - refined lead contained in exported products + adjustments for government and industry stock changes. Boxes represent sources of lead; numbers represent 2004 flow estimates expressed in thousand metric tons of lead metal, as adapted from data reported by the U.S. International Trade Commission, 2005 (colored boxes) and the U.S. Geological Survey Mineral Commodity Summaries 2006 (Gabby, 2006). Numbers may not total because of individual rounding.

attributed to the inclusion of lead contained in imported and exported manufactured products in the total consumption statistics. Minor variations in data comprehensiveness and estimation methodology may also affect results.

The lead-acid battery sector is the principal end use of lead in the United States, accounting for approximately 81 percent of the reported U.S. lead consumption in 2003 (Matos and others, 2005), 83 percent in 2004 (Gabby, 2005), and 85 percent in 2005 (Gabby, 2006). Lead-acid batteries include starting-lighting-ignition batteries for vehicles (accounting for about 87 percent of lead-acid batteries by weight), stationary, uninterruptible power-supply equipment for computer and telecommunications networks and hospitals (about 8 percent), and as a source of motive power in airline ground equipment, golf carts, industrial forklifts, and mining vehicles (about 5 percent) (Battery Council International, 2005a). The lead-acid battery, similar to the automotive battery shown in figure 2, is an example of a manufactured product that can be tracked through the economy. These widely used batteries are highly recyclable, are an important component of total U.S. lead consumption, and are reported separately in trade statistics. The potential toxicity of lead-acid batteries makes quantifying the use of these products within the United States important. For these reasons, the lead-acid battery sector was selected as a case study for this lead consumption analysis.

The potentially toxic effects of lead on organisms have become widely recognized since the mid-1980s, resulting in

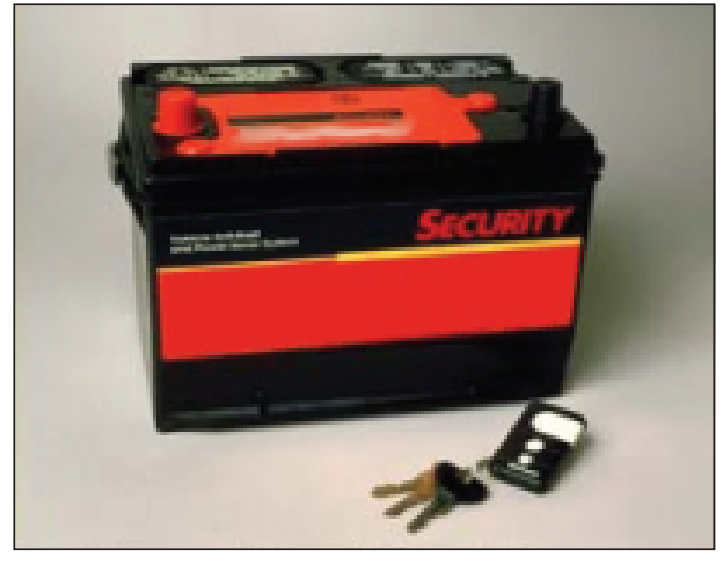

Figure 2. Approximately 81 percent of all lead consumed in the United States goes into lead-acid storage batteries. A typical lead-acid automotive battery contains about 9.75 kilograms of lead. Photograph courtesy of Delphi Automotive Systems, Inc. 
Federal, State, and local legislation governing lead production, trade, domestic use, and disposal, which in turn have influenced lead end-use patterns, the amount of product recycling, and U.S. trade. Compliance with environmental regulations has significantly reduced or eliminated the use of lead in nonbattery applications (such as gasoline, nonmilitary ammunition, paints, solders, and water systems). Since 1989, most states have passed legislation prohibiting the disposal of lead-acid batteries in landfills and incinerators and requiring retailers to accept used batteries for recycling when consumers purchase new batteries (Battery Council International, 2005b). Lead-acid battery recovery for recycling has increased from about 70 percent in 1980 to about 93 percent in 2003 as a growing number of communities and States have restricted lead-acid batteries from disposal at landfills or combustors (U.S. Environmental Protection Agency, 2005). In 2005, the Battery Council International released a study reporting a recycling rate for lead-acid batteries of about 99 percent for the 1999 to 2003 period (Battery Council International, 2005a). While lead use in other applications has declined, the total amount of lead contained in lead-acid vehicle batteries has generally continued to grow, primarily because of increasing vehicle sales in the United States.

\section{Study Methodology}

In 1999, the USGS reported the amount of lead contained in imported and exported products from 1972 through 1993 based upon an input-output methodology developed by the U.S. Department of Commerce in consultation with the USGS. This methodology used U.S. gross domestic product data, manufactured products import and export data by industrial sector, and raw material consumption data. The study covered a time period when lead-acid battery consumption increased from about 50 percent to about 84 percent of total lead consumption. Owing to the changed structure of the sector and the dated nature of the prior study data, a reevaluation of consumption was thought to be warranted; however, a simpler methodology was selected to study the lead-acid battery sector.
The earlier study estimated total annual lead-acid battery consumption using data provided for the entire U.S. economy and assigning a set of mathematical relationships between the lead-acid battery sector and the domestic economy. The current study, however, used actual U.S. consumption statistics reported for specified products as the basis of evaluation; data for each product category were aggregated to develop annual consumption values for the sector under study. A comparison of study results is given below.

The authors evaluated apparent consumption statistics reported by the USGS from its Mineral Commodity Summaries series (U.S. Bureau of Mines, 1994; Smith, 1995-2004; Gabby, 2005-06) and lead-acid battery import and export trade data, reported either in terms of number of lead-acid batteries or kilograms of contained lead, obtained from data collected by the U.S. Bureau of the Census and reported by the USITC (U.S. International Trade Commission, 2005) based on Harmonized Tariff Schedule (HTS) codes. Import and export data were collected for new and used lead-acid batteries, vehicle imports and exports (which included lead-acid batteries), stationary lead-acid batteries, other motive power lead-acid battery types (for example, aircraft ground maintenance, general utility vehicles, golf cart, and marine), and battery parts containing lead (plates and posts).

Estimates of the average lead content included in each HTS code were developed. Because individual HTS codes may include more than one lead-acid battery type, it was necessary to review each classification to determine the appropriate distribution of battery types reported for each. For codes where only the numbers of batteries were reported, an estimate for the average amount of lead contained within each lead-acid battery type reported under that classification was developed, so that an estimate of the total amount of lead contained in that classification could be made. Lead content estimates were based on generalized data provided by the Battery Council International (Battery Council International, 2003, 2005a) and by Peter Gabby, the USGS lead commodity specialist (USGS, oral commun., 2006). Estimates for the average amount of lead contained in generalized battery types are summarized in table 1.

\section{Table 1. Average lead content estimates.}

[Lead content in pounds (lbs) reported by Battery Council International (2005a); lead content in kilograms (kg) based on 2.2046 lbs/kg conversion factor]

\begin{tabular}{llcc}
\hline \multicolumn{1}{c}{ Classification } & \multicolumn{1}{c}{ Lead-acid battery types } & $\begin{array}{c}\text { Weight of lead } \\
\text { in battery, in pounds }\end{array}$ & $\begin{array}{c}\text { Weight of lead } \\
\text { in battery, in kilograms }\end{array}$ \\
\hline Golf cart & Golf carts or similar vehicles & 41.1 & 18.6 \\
Marine & Speed boats, trolling craft & 30.9 & 14.0 \\
Military vehicle & Motorized fighting vehicles, tanks & 44.0 & 20.0 \\
Large stationary & Uninterruptible power supply equipment & 1,800 & 816 \\
Small motive & Airline ground equipment or similar motive equipment & 38.0 & 17.2 \\
Passenger car/light truck & Passenger cars, light trucks & 21.5 & 9.7 \\
Speciality vehicle & Industrial forklifts, mining equipment, or similar equipment & 25.0 & 11.3 \\
Tractor & Tractors & 33.0 & 15.0 \\
Truck and heavy duty & Trucks, heavy duty vehicles & 38.7 & 17.5 \\
Utility & Special purpose motor vehicles & 9.1 & 4.1 \\
\hline
\end{tabular}


The amount of lead contained in lead-acid batteries varies significantly with battery type and slightly by manufacturer. Estimates of average lead content were developed using representative lead content values for each battery classification.

\section{Analysis of Results}

Table 2 summarizes the data for the amount of lead contained in U.S. lead-acid battery imports and exports for selected years within the 1989 through 2004 study period. Trade classifications included in this analysis are also reported in table 2. Estimates for 2004 suggest that the United States imported about 2.4 times more lead contained in lead-acid battery products than it exported. About 75 percent of the imported lead in batteries was contained in new lead-acid batteries, and about 22 percent comes into the United States as batteries contained in vehicles. Less than 3 percent of the lead contained in imported lead-acid batteries comes into the United States as either used batteries or battery parts. About 66 percent of the lead exported in lead-acid batteries is in the form of new batteries; 14 percent is exported in used lead-acid batteries; about 10 percent is exported in batteries contained in vehicles; and another 10 percent is exported in battery parts. The data also suggest that, for the study period, the
United States is a net importer of lead contained in lead-acid batteries. In 2004, it imported about 293,000 t more lead contained in lead-acid batteries than it exported.

Figure 3 compares annual U.S. lead-acid battery apparent consumption with estimated U.S. lead-acid battery total consumption of lead. Apparent consumption data (blue line) were modified from USGS data to reflect that part of U.S. lead metal consumption attributed to the lead-acid battery sector, based on USGS end-use statistics (Matos and others, 2005). Total consumption data (red line) were developed in this analysis to include the U.S. consumption of lead in concentrate, refined metal imports and exports, and as lead contained in imported and exported manufactured lead-acid battery products. Figure 3 does not include lead from other end-use sectors (or about 15 percent of total lead consumption).

Because the United States imported more lead contained in lead-acid batteries than it exported in lead-acid batteries for the period 1989 through 2004, the difference between these two data sets reflects the net amount of imported lead contained in lead-acid batteries, which is also shown in figure 3 (green line). The estimated value of U.S. total lead consumption for the lead-acid battery sector was found to be larger than the estimated value of apparent consumption for each year of the 16-year study. The difference between these two values varied from a minimum of approximately 74,000 $t$ in 1997, when U.S. total lead-acid battery consumption was about

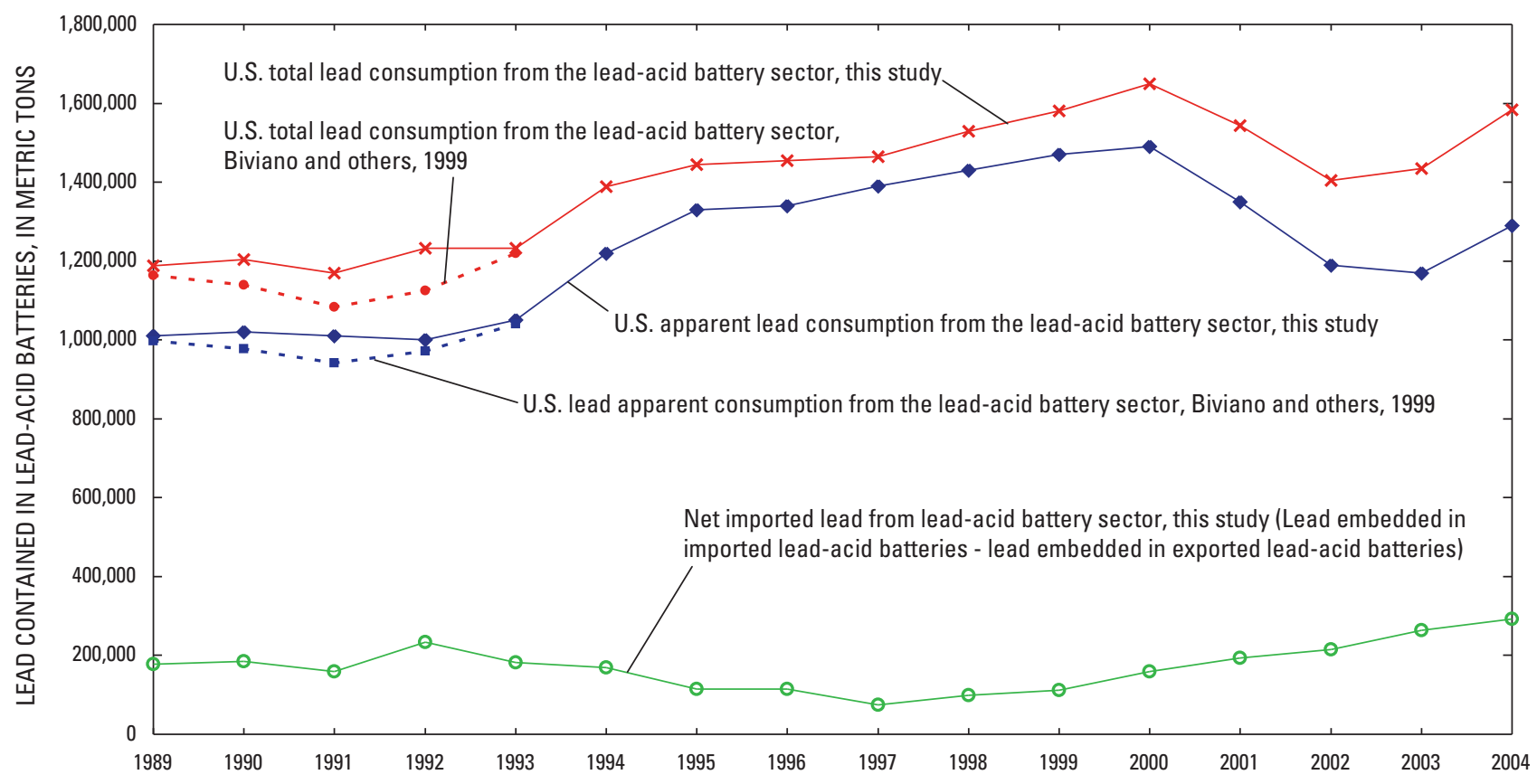

Figure 3. Comparison of lead apparent consumption data with total consumption data for the lead-acid battery sector for the years 1989 through 2004. [Lead apparent consumption is defined as mine production + secondary refined + imports (concentrates and refined) - exports (concentrates and refined) + adjustments for government and industry stock changes. Total consumption is defined as primary and secondary refined lead production + refined lead metal imports for consumption + lead contained in imported lead-acid battery products - refined lead exports - lead contained in exported lead-acid battery products + adjustments for government and industry stock changes. Data from this study are also compared to data from a 1999 U.S. Geological Survey (USGS) study, Biviano and others, 1999]. 
4 percent higher than U.S. apparent consumption for the sector, to a maximum of approximately $293,000 \mathrm{t}$ in 2004 , when U.S. total lead-acid battery consumption was about 24 percent higher than U.S. apparent consumption for the sector.

Overlapping data from the 1999 lead consumption study (Biviano and others, 1999) are also presented in figure 3. On average for the 5-year period where the studies overlapped (1989 to 1993), the earlier study showed that including the amount of lead contained in lead-acid battery products increased the total U.S. lead consumption about 16 percent, while the present study suggests an increase of about 18 percent. The average difference between the two studies, less than 5 percent, is believed to be the result of source data and study methodology differences.

Considering lead contained in manufactured products provides more comprehensive data for analyzing the use, disposal, and recycling of lead in the United States and for better understanding the factors that affect consumption. Including the lead contained in imported products as part of the analysis of lead consumption makes it easier to understand how U.S. secondary lead production has grown since regulations were implemented to require the recycling of products containing lead. In 2004, the United States recovered approximately 1.1 Mt of lead scrap metal from lead product recycling (fig. 1), about twice the amount that was recovered by recycling in 1985. It would be difficult to tell where the bulk of this recycled material originated without considering the amount of lead contained in imported manufactured products.
Ignoring residence time, figure 1 suggests that the combination of 2004 U.S. primary production and refined lead imports could only supply about one-third (350,000 t) of the feed material necessary to account for the annual production level reported for the U.S. secondary (recycling) lead production sector in 2004 (1.1 Mt).

Consumption studies of this type can also provide data in sufficient detail to evaluate the effects of such things as industry structural changes, domestic and foreign legislation, and changing trade patterns of the sector under review. For example, figure 4 compares the quantity of new lead-acid batteries imported into the United States from all countries with the quantity imported from Mexico. Data suggest that a large part of the increase in the number of new lead-acid batteries (and the amount of lead coming into the United States) since 1997 is the result of a corresponding increase in U.S. lead-acid battery imports from Mexico. Legislation such as the North American Free Trade Agreement (NAFTA), which became effective January 1, 1994, between Canada, Mexico, and the United States, as well as bilateral trade agreements initiated between 1994 and 1996, removed many product trade restrictions applied to such products as lead-acid batteries between these three neighboring countries (U.S. Environmental Protection Agency, 1998). In a report to Congress in 1999, the increase in lead-acid battery trade with Mexico after the implementation of NAFTA was specifically noted (U.S. International Trade Administration, 1999).

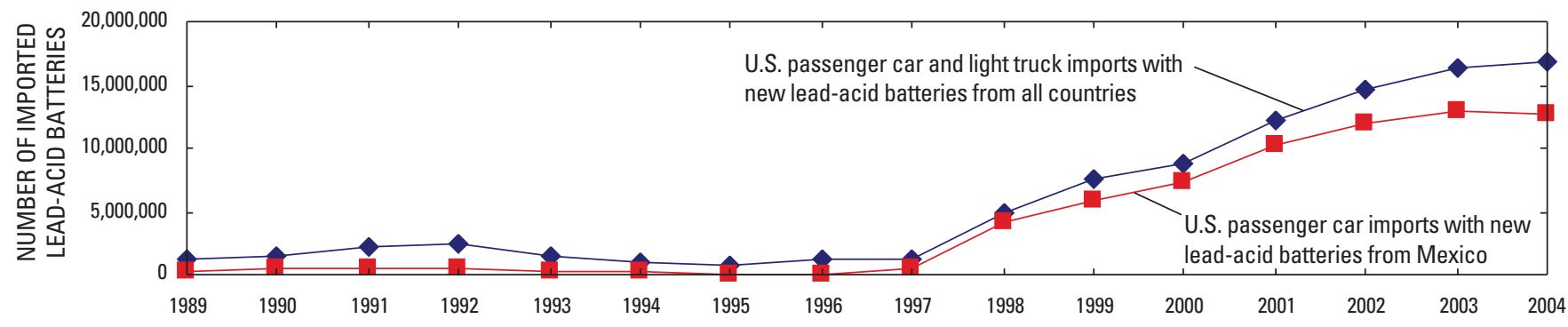

Figure 4. Comparison of new lead-acid battery imports to the United States with imports from Mexico. Data from International Trade Commission (2005). 
Table 2. Lead contained in U.S. imported and exported lead-acid batteries and battery parts for selected years between 1989 and 2004.

[Data are reported in kilograms of contained lead contained in selected manufactured products, modified from U.S. International Trade Commission (ITC, 2005) using lead content data from Battery Council International (2003, 2005a), and discussions with Peter Gabby (U.S. Geological Survey, oral commun., 2005)]

\begin{tabular}{|c|c|c|c|c|c|c|c|c|}
\hline \multirow{2}{*}{ Classification } & \multicolumn{2}{|c|}{1989} & \multicolumn{2}{|c|}{1992} & \multicolumn{2}{|c|}{1995} & \multicolumn{2}{|c|}{1998} \\
\hline & Imports & Exports & Imports & Exports & Imports & Exports & Imports & Exports \\
\hline \multicolumn{9}{|c|}{ New lead-acid batteries } \\
\hline Motive $^{1}$ & $21,725,000$ & 624,000 & $23,521,000$ & 770,000 & $63,214,000$ & $12,479,000$ & $109,694,000$ & $18,302,000$ \\
\hline Vehicle $^{2}$ & $141,389,000$ & $41,840,000$ & $202,953,000$ & $70,516,000$ & $65,088,000$ & $86,029,000$ & $90,828,000$ & $116,380,000$ \\
\hline
\end{tabular}

\begin{tabular}{|c|c|c|c|c|c|c|c|c|}
\hline \multicolumn{9}{|c|}{ Used lead-acid batteries } \\
\hline Motive $^{3}$ & 198,000 & $29,907,000$ & 502,000 & $12,625,000$ & 326,000 & 241,000 & 0 & 0 \\
\hline Vehicle $^{4}$ & 555,000 & $1,315,000$ & $4,407,000$ & 233,000 & $8,668,000$ & 845,000 & $5,099,000$ & $1,685,000$ \\
\hline Other $^{5}$ & $4,099,000$ & $5,884,000$ & $1,891,000$ & $2,169,000$ & $2,779,000$ & $17,349,000$ & $3,205,000$ & $27,432,000$ \\
\hline
\end{tabular}

Subtotal: Lead-acid batteries

$\begin{array}{llllllll}167,966,000 & 79,570,000 & 233,274,000 & 86,313,000 & 140,075,000 & 116,943,000 & 208,826,000 & 163,799,000\end{array}$

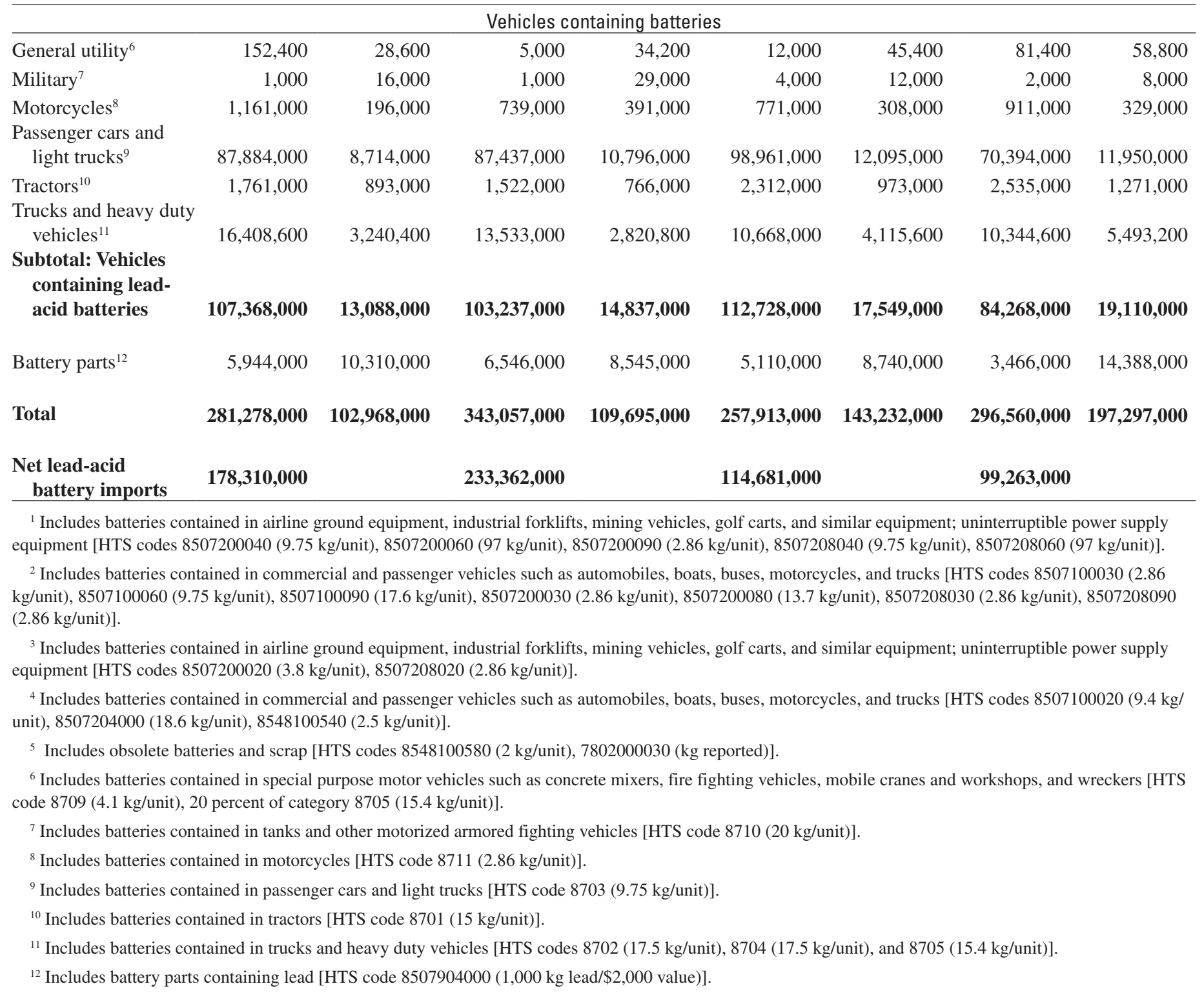


Table 2. Lead contained in U.S. imported and exported lead-acid batteries and battery parts for selected years between 1989 and 2004.-Continued

[Data are reported in kilograms of contained lead contained in selected manufactured products, modified from U.S. International Trade Commission (ITC, 2005) using lead content data from Battery Council International (2003, 2005a), and discussions with Peter Gabby (U.S. Geological Survey, oral commun., 2005)]

\begin{tabular}{|c|c|c|c|c|c|c|}
\hline \multirow{2}{*}{ Classification } & \multicolumn{2}{|c|}{2001} & \multicolumn{2}{|c|}{2003} & \multicolumn{2}{|c|}{2004} \\
\hline & Imports & Exports & Imports & Exports & Imports & Exports \\
\hline \multicolumn{7}{|c|}{ New lead-acid batteries } \\
\hline Motive $^{1}$ & $117,670,000$ & $20,298,000$ & $151,658,000$ & $14,387,000$ & $160,216,000$ & $20,933,000$ \\
\hline Vehicle $^{2}$ & $180,580,000$ & $132,343,000$ & $205,773,000$ & $127,074,000$ & $217,442,000$ & $120,509,000$ \\
\hline \multicolumn{7}{|c|}{ Used lead-acid batteries } \\
\hline Motive $^{3}$ & 0 & 0 & 0 & 0 & 0 & 0 \\
\hline Vehicle $^{4}$ & $4,591,000$ & $1,134,000$ & $10,299,000$ & $1,364,000$ & $11,788,000$ & $1,047,000$ \\
\hline Other ${ }^{5}$ & 639,000 & $12,119,000$ & 305,000 & $27,350,000$ & 385,000 & $28,607,000$ \\
\hline $\begin{array}{l}\text { Subtotal: Lead-acid } \\
\text { batteries }\end{array}$ & $303,480,000$ & $165,894,000$ & $368,035,000$ & $170,175,000$ & $389,831,000$ & $171,096,000$ \\
\hline \multicolumn{7}{|c|}{ Vehicles containing batteries } \\
\hline General utility ${ }^{6}$ & 175,600 & 65,400 & 179,000 & 63,200 & 160,000 & 91,600 \\
\hline Military $^{7}$ & 1,000 & 9,000 & 2,000 & 5,000 & 2,000 & 18,000 \\
\hline Motorcycles $^{8}$ & $3,170,000$ & 293,000 & $10,281,000$ & 389,000 & $12,925,000$ & 351,000 \\
\hline $\begin{array}{l}\text { Passenger cars and } \\
\text { light trucks }{ }^{9}\end{array}$ & $70,619,000$ & $12,737,000$ & $73,783,000$ & $13,425,000$ & $78,954,000$ & $13,743,000$ \\
\hline Tractors ${ }^{10}$ & $2,097,000$ & 761,000 & $3,219,000$ & 773,000 & $4,116,000$ & 978,000 \\
\hline $\begin{array}{l}\text { Trucks and heavy duty } \\
\text { vehicles }^{11}\end{array}$ & $14,136,400$ & $4,861,600$ & $13,850,000$ & $5,567,800$ & $12,922,000$ & $6,224,400$ \\
\hline $\begin{array}{l}\text { Subtotal: Vehicles } \\
\text { containing lead- } \\
\text { acid batteries }\end{array}$ & $90,199,000$ & $18,727,000$ & $101,314,000$ & $20,223,000$ & $109,079,000$ & $21,406,000$ \\
\hline Battery parts ${ }^{12}$ & $5,993,000$ & $21,347,000$ & $5,526,000$ & $20,272,000$ & $7,353,000$ & $21,236,000$ \\
\hline Total & $399,672,000$ & $205,968,000$ & $474,875,000$ & $210,670,000$ & $506,263,000$ & $213,738,000$ \\
\hline $\begin{array}{l}\text { Net lead-acid } \\
\text { battery imports }\end{array}$ & $193,704,000$ & & $264,205,000$ & & $292,525,000$ & \\
\hline
\end{tabular}




\section{Summary}

Including statistical data on mineral commodities contained in manufactured products provides a more complete perspective of mineral use, disposal, and recycling in the United States. Inclusion of net trade data on lead-containing products added about 340,000 t to the reported 2004 U.S. lead apparent consumption value from all sectors, an increase of about 24 percent. For the lead-acid battery sector, inclusion of lead contained in imported and exported batteries, vehicles containing batteries, and battery products increased 2004 U.S. lead consumption by approximately 293,000 t. Considering lead contained in manufactured products as part of total lead consumption allows for a more complete understanding of the use, disposal, and recycling of lead in the United States. Observing trends related to trade of these products allows for more detailed analysis of the effects of domestic and foreign legislation, economic activity, and evaluation of sector trade.

The data suggest that approximately 293,000 t of lead contained in net imports of lead-acid battery products were consumed in the United States in 2004. Assuming lead-acid batteries account for 85 percent of total U.S. lead consumption, an additional $340,000 \mathrm{t}$ of lead contained in net imports from all sectors can be added to the U.S. lead consumption. This quantity is over twice the U.S. refined lead production for 2004 from the primary lead industry and almost three times the net amount of refined lead metal imported for consumption in 2004.

\section{References Cited}

Battery Council International, 2003, National recycling rate study: Chicago, Ill., Smith, Bucklin, and Associates, Inc., July, 11 p.

Battery Council International, 2005a, National recycling rate study: Chicago, Ill., Smith, Bucklin, and Associates, Inc., June, 11 p., accessed October 30, 2006, at http://www. batterycouncil.org/BCIRecylingRateStudyReport.pds

Battery Council International, 2005b, Summary of U.S. State lead-acid battery laws: Battery Council International, accessed December 2, 2005, at http://www.batterycouncil. org/states.html

Biviano, M.B., Sullivan, D.E., and Wagner, L.A., 1999, Total materials consumption-An estimation methodology and example using lead-A materials flow analysis: U.S. Geological Survey Circular 1183, accessed November 23, 2005 , at http://pubs.usgs.gov/circ/1999/c1183/

Gabby, P.N., 2005, Lead: U.S. Geological Survey Mineral Commodity Summaries 2005, p. 94-95, accessed October 30, 2006, at http://minerals.er.usgs.gov/minerals/pubs/ commodity/lead/lead_mcs05.pdf
Gabby, P.N., 2006, Lead: U.S. Geological Survey Mineral Commodity Summaries 2006, p. 96-97, accessed October 30, 2006, at http://minerals.er.usgs.gov/minerals/pubs/ commodity/lead/lead_mcs06.pdf

Matos, G.R., Smith, G.R., and Gabby, P.N., 2005, Lead enduse statistics, in Kelly, T.D., and Matos, G.R., eds., Historical statistics for mineral and material commodities in the United States (version 1.0): U.S. Geological Survey Data Series 2005-140, accessed January 11, 2006, at http:// minerals.er.usgs.gov/minerals/pubs/ds05-140/lead-use.pdd

Smith, G.R., 1995, Lead: U.S. Bureau of Mines Mineral Commodity Summaries 1995, p. 94-95.

Smith, G.R., 1996, Lead: U.S. Bureau of Mines and U.S. Geological Survey Mineral Commodity Summaries 1996, p. 92-93, accessed October 30, 2006, at http://minerals. er.usgs.gov/minerals/pubs/commodity/lead/lead_mcs96.pdf

Smith, G.R., 1997, Lead: U.S. Geological Survey Mineral Commodity Summaries 1997, p. 94-95, accessed October 30, 2006, at http://minerals.er.usgs.gov/minerals/pubs/ commodity/lead/380397.pdf

Smith, G.R., 1998, Lead: U.S. Geological Survey Mineral Commodity Summaries 1998, p. 94-95, accessed October 30, 2006, at http://minerals.er.usgs.gov/minerals/pubs/ commodity/lead/380398.pdf

Smith, G.R., 1999, Lead: U.S. Geological Survey Mineral Commodity Summaries 1999, p. 98-99, accessed October 30, 2006, at http://minerals.er.usgs.gov/minerals/pubs/ commodity/lead/380399.pdf

Smith, G.R., 2000, Lead: U.S. Geological Survey Mineral Commodity Summaries 2000, p. 96-97, accessed October 30, 2006, at http://minerals.er.usgs.gov/minerals/pubs/ commodity/lead/380300.pdf

Smith, G.R., 2001, Lead: U.S. Geological Survey Mineral Commodity Summaries 2001, p. 92-93, accessed October 30, 2006, at http://minerals.er.usgs.gov/minerals/pubs/ commodity/lead/380301.pdf

Smith, G.R., 2002, Lead: U.S. Geological Survey Mineral Commodity Summaries 2002, p. 94-95, accessed October 30, 2006, at http://minerals.er.usgs.gov/minerals/pubs/ commodity/lead/380302.pdf

Smith, G.R., 2003, Lead: U.S. Geological Survey Mineral Commodity Summaries 2003, p. 96-97, accessed October 30, 2006, at http://minerals.er.usgs.gov/minerals/pubs/ commodity/lead/380303.pdf

Smith, G.R., 2004, Lead: U.S. Geological Survey Mineral Commodity Summaries 2004, p. 94-95, accessed October 30, 2006, at http://minerals.er.usgs.gov/minerals/pubs/ commodity/lead/leadmcs04.pdf 
U.S. Bureau of Mines, 1994, Lead: U.S. Bureau of Mines Mineral Commodity Summaries 1994, p. 98-99.

U.S. Environmental Protection Agency, 1998, International trade in hazardous waste-An overview: U.S. Environmental Protection Agency enforcement and compliance assurance document 2222A, EPA-305-K-98-001, November, 5 p.

U.S. Environmental Protection Agency, 2005, Municipal solid waste generation, recycling, and disposal in the United States-Facts and figures for 2003: U.S. Environmental Protection Agency, 11 p., accessed March 27, 2006, at http://www.epa.gov/msw/msw/05rpt.pdf
U.S. International Trade Administration, 1999, Fifth annual report to Congress regarding the impact of the North American Free Trade Agreement upon U.S. automotive trade with Mexico: U.S. International Trade Administration, [Pagination unknown], accessed November 27, 2005, at $h t t p: / / w w w$. mac.doc.gov/nafta/autos99.html

U.S. International Trade Commission, 2005, Interactive tariff and trade dataweb: U.S. International Trade Commission, accessed July 19, 2005, at http://dataweb.usitc.gov
Manuscript approved for publication, October 2, 2006

Edited by M.A. Billone

Graphics by J.E. Banton

Layout by K.A. Waltenbaugh

For more information concerning research in this report, contact USGS

Minerals and Materials Analysis Section, telephone: 303-236-8747 